\title{
Waardenburg syndrome type 2
}

INSERM

\section{Source}

INSERM. (1999). Orphanet: an online rare disease and orphan drug data base.

Waardenburg syndrome type 2. ORPHA:895

Waardenburg syndrome type 2 (WS2) is an autosomal dominant subtype of Waardenburg syndrome (WS; see this term), characterized by varying degrees of deafness and pigmentation anomalies of eyes, hair and skin, but without dystopia canthorum. 